\title{
Production of Cytokines in Patients with Primary Pulmonary Mycobacterium Avium-intracellulare Complex Disease
}

\author{
MIKIKO EMORI \\ Department of Medicine, Kurume University School of Medicine, \\ Kurume 830-0011, Japan
}

\begin{abstract}
Summary: To clarify the immunological state of patients with pulmonary Mycobacterium aviumintracellulare complex (MAC) disease, we compared the production of IFN- $\gamma$, IL-10 and TNF- $\alpha$ by peripheral blood mononuclear cells (PBMC) between MAC disease patients with different levels of disease activity and healthy volunteers. The patients had no complication of systemic immunological diseases or preexisting pulmonary diseases. PBMC obtained from 46 patients and 15 healthy control volunteers were incubated with a protein antigen extracted from Mycobacterium intracellulare (PPD-B) for seven days, and IFN- $\gamma$, IL-10 and TNF- $\alpha$ concentration in the supernatant of the cultures was measured by enzyme-linked immunosorbent assay (ELISA). We categorized the patients into 3 groups based on the findings of chest radiography or results of sputum culture for MAC: group I in a stable state of the disease activity (15 patients), group II in an unstable state (16 patients) and group III in an active state of the disease (15 patients). IFN- $\gamma$ was low in all three patient groups compared to the healthy group. There was no difference of the concentration of IFN- $\gamma$ among the three patient groups. IL-10 was high in the patient groups compared to the healthy group, and the concentration of IL-10 in the patients of groups II and III was significantly higher than in the healthy group. Although the production of TNF- $\alpha$ in group I was significantly suppressed compared to the healthy group, the production of TNF- $\alpha$ was significantly elevated in groups II and III compared to group I. There was no difference in the production of these cytokines between the patients of group III with tuberculosis-like form and with nodular-bronchietasis form. These findings suggested that the Th1-type reaction in the patients with primary pulmonary MAC disease is suppressed (lower than the healthy persons) irrespective of the disease activity state and that the Th2-type reaction is increased in parallel with disease activity.
\end{abstract}

Key words pulmonary MAC disease, cell-mediated immunity, IFN- $\gamma$, IL-10,TNF- $\alpha$

\section{INTRODUCTION}

Mycobacterium avium-intracellulare complex (MAC) is ubiquitous in the environment and it has been thought to be an opportunistic pathogen i.e., to show pathogenicity in immunocompromised hosts or persons with preexisting pulmonary diseases such as chronic obstructive pulmonary disease (COPD). Accordingly, the MAC infectious disease is found in a high percentage of patients [1] in advanced stage of the human immunodeficiency virus (HIV) infectious disease, when peripheral blood CD4 positive T lym- phocytes are less than $200 / \mu l$. Thus, the main defense mechanism of host against MAC is thought to be cell-mediated immunity.

However, MAC has been recognized [2-5] to cause pulmonary disease in immunocompetent persons without preexisting pulmonary disease, i.e., to cause primary pulmonary MAC disease. The prognosis of primary pulmonary MAC disease is poor, because this is a chronic, slowly progressing, disease and because few anti-microbial agents against MAC are available. There are two forms of primary pulmonary MAC disease, distinguished on the basis of

Received for publication March 15, 2004

Abbreviations: COPD, chronic obstructive pulmonary disease; ELISA, enzyme-linked immunosorbent assay; HIV, human immunodeficiency virus; MAC, Mycobacterium avium-intracellulare complex; NB, nodular-bronchiectasis; PBMC, peripheral blood mononuclear cells; PPD-B, purified protein derivative $B$ extracted from Mycobacterium intracellulare; TB, tuberculosis-like. 
the chest radiographic features. One form, tuberculosis-like (TB) form, resembles pulmonary tuberculosis, while the other form, nodular-bronchiectasis (NB) form, is associated with mid-lung infiltrate and bronchiectasis in older females. The TB form progresses about twice as fast as the NB form. The immunological mechanism underlying the primary pulmonary MAC disease has not been well clarified, but it seems to be different from that underlying the MAC infectious disease in the patients with HIV infectious disease.

This study was done to clarify the immunological features of the patients with primary pulmonary MAC disease by comparing the cytokine-producing ability of peripheral blood mononuclear cells (PBMC) in response to MAC antigen with the disease activity.

\section{SUBJECTS AND METHODS}

Forty six patients (14 male and 32 female, mean age $\pm \mathrm{SD}, 67.9 \pm 10.8$ years) with primary pulmonary MAC infectious disease and 15 healthy volunteers (one male and 14 female, 55.2 \pm 13.4 years) were studied. Patients were followed as outpatients or admitted to the National Oomuta Hospital from 1999 to 2001. Diagnosis was made on the criteria [6] recommended by the American Thoracic Society for the diagnosis of disease caused by nontuberculous mycobacteria. In all cases, results of sputum or bronchial lavage fluid culture was positive for $\mathrm{M}$. avium or $\mathrm{M}$. intracellulare at some stage of the disease. The patients had no complication of systemic immunological diseases or preexising pulmonary diseases such as COPD or obsolete pulmonary tuberculosis. The patients had been treated with antimycobacterial agents but never received any immuno- suppressive and or anti-inflammatory drugs.

The control healthy volunteers agreed to join this study and showed no abnormality upon blood laboratory examination and chest $\mathrm{X}$-ray examination (Table 1).

\section{Clinical laboratory}

The patients were examined by the clinical laboratory examination (Table 2). In addition, three respiratory medical specialists reviewed all the chest Xray and thorax computed tomography data of each patient, and classified the patients into NB form and TB form and evaluated the present state of disease activity. The disease was presumed to be active when the patient's chest radiography showed deterioration of the lung at least once within the past one year or MAC was cultured from the sputum within the past 6 months.

Assay of cytokine production by PBMC after stimulation with purified protein derivative- $B$ (PPD-B) in vitro

The assay was carried out as described by Harada et al [7]. Briefly, heparinized venous blood obtained from the patients and healthy subjects was diluted two fold with physiological saline, and PBMCs were isolated by density centrifugation over Lymphoprep (Nycomed Pharma). After the lymphocyte counts were adjusted to $1 \times 10^{6} / \mathrm{ml}$, PBMCs were suspended in a culture medium RPMI1640 containing $20 \%$ heat-inactivated normal human $\mathrm{AB}$ serum, L-glutamine $0.3 \mathrm{mg} / \mathrm{ml}$, penicillin $100 \mathrm{U} / \mathrm{ml}$ and streptomycin $100 \mu \mathrm{g} / \mathrm{ml}$. To $1 \mathrm{ml}$ of the PBMC mixture in a test tube was added $0.1 \mathrm{ml}$ of $5 \mu \mathrm{g} / \mathrm{ml}$ of PPD-B fluid, and to another $1 \mathrm{ml}$ of the PBMC mixture in a matched control tube was added $0.1 \mathrm{ml}$ of distilled water, then they were incubated for 7 days at $37^{\circ} \mathrm{C}$ in

TABLE 1.

Characteristics of the patients with primary pulmonary MAC disease and healthy volunteers

\begin{tabular}{|c|c|c|c|c|c|c|c|c|}
\hline \multirow[t]{2}{*}{ subject } & \multirow[t]{2}{*}{ no. } & \multicolumn{2}{|c|}{$\operatorname{sex}$} & \multirow{2}{*}{$\begin{array}{c}\text { age } \\
\text { (years) }\end{array}$} & \multicolumn{2}{|c|}{$\begin{array}{c}\text { X-ray signs of } \\
\text { deterioration }\end{array}$} & \multicolumn{2}{|c|}{$\begin{array}{c}\text { sputum culture for } \\
\text { MAC }\end{array}$} \\
\hline & & male & female & & - & + & - & + \\
\hline $\begin{array}{l}\text { patients } \\
\text { (total number) }\end{array}$ & 46 & 14 & 32 & $67.9 \pm 10.8$ & 31 & 15 & 31 & 15 \\
\hline NB form & 35 & 10 & 25 & $69.2 \pm 10.6$ & 21 & 14 & 29 & 6 \\
\hline TB form & 11 & 4 & 7 & $63.9 \pm 12.3$ & 10 & 1 & 2 & 9 \\
\hline healthy volunteers & 15 & 1 & 14 & $55.2 \pm 13.4$ & & & & \\
\hline
\end{tabular}


TABLE 2.

Results of blood laboratory examination and body weight of the patients

\begin{tabular}{|c|c|c|c|c|c|c|c|c|c|c|}
\hline patient group & no. & & $\begin{array}{c}\mathrm{ESR} \\
\mathrm{mm} / \mathrm{h}\end{array}$ & $\begin{array}{l}\text { CRP } \\
\mathrm{mg} / \mathrm{dl}\end{array}$ & $\begin{array}{c}\text { WBC } \\
\mid \mu l\end{array}$ & $\begin{array}{l}\text { Lym } \\
\mid \mu l\end{array}$ & $\begin{array}{l}\text { Mo } \\
\mid \mu 1\end{array}$ & $\begin{array}{c}\text { T. Prot. } \\
\text { g/dl }\end{array}$ & $\begin{array}{l}\text { Alb } \\
\text { g/dl }\end{array}$ & $\begin{array}{c}\mathrm{BW} \\
\mathrm{kg}\end{array}$ \\
\hline \multirow[t]{2}{*}{ Group I } & & mean & 17.9 & 0.11 & $4,000.0$ & $1,248.7$ & 230.1 & 6.9 & 4.0 & 46.2 \\
\hline & $1 J$ & SD & 14.5 & 0.15 & $1,099.4$ & 435.3 & 65.3 & 0.5 & 0.2 & 7.4 \\
\hline \multirow{3}{*}{ Group II } & & mean & $32.0 * 1$ & 0.83 & $5,056.3 * 1$ & $1,391.1$ & 283.9 & 7.1 & 3.9 & 48.2 \\
\hline & 16 & & & & & & & & & \\
\hline & & SD & 23.6 & 1.38 & $1,499.8$ & 411.8 & 118.5 & 0.5 & 0.4 & 11.9 \\
\hline \multirow{3}{*}{ Group III } & & mean & $44.4 * 1$ & $1.43 * 1$ & $5,306.7 * 1$ & $1,338.8$ & 268.7 & 7.1 & $3.6 * 1, * 2$ & $39.8 * 1, * 2$ \\
\hline & 15 & & & & & & & & & \\
\hline & & SD & 29.1 & 1.73 & $1,658.5$ & 486.2 & 111.6 & 0.7 & 0.4 & 6.1 \\
\hline
\end{tabular}

SD; standard deviation, ESR; erythrocyte sedimentation rate, CRP; C reactive protein, WBC; white blood cell, Lym; lymphocyte, Mo; monocyte, T. Prot.; total protein, Alb; albumin, BW; body weight

${ }^{* 1} ; \mathrm{p}<0.05$ vs group I, ${ }^{* 2} ; \mathrm{p}<0.05$ vs group II

a 5\% $\mathrm{CO}_{2}$ atmosphere. The PPD-B, a protein antigen extracted from M. intracellulare, was provided by Dr. Hironobu Tasaka [8]. After incubation, the numbers of lymphocyte and monocyte in the culture fluids were counted. The culture supernatants were stored at $-20^{\circ} \mathrm{C}$.

Concentration of cytokines in the culture supernatants was measured by enzyme linked immunosorbent assay (ELISA). ELISA kits were used to measure concentrations of IFN- $\gamma$, IL-10 (Immunotech) and TNF- $\alpha$ (BML). The concentration of IFN- $\gamma$ was expressed as the value per $1 \times 10^{6}$ lymphocytes in culture fluids and those of IL-10 and TNF- $\alpha$ were expressed as the value per $1 \times 10^{6}$ mononuclear cells in culture fluids.

\section{Statistical analysis}

Data are shown as the mean \pm standard deviation. Statistical analysis was done by unpaired Student's t test or Cochran and Cox's method after the equality of variance between two groups was examined by $\mathrm{F}$ test.

\section{RESULTS}

Characteristics of the patients and healthy volunteers are shown on Table 1. In addition to the classification into NB or TB form,based on the chest Xray picture, the patients were classified into three groups on the basis of the clinical findings. The deterioration $(-)$ /culture $(-)$ (group I) was a group of patients whose disease state inactive and stable. The deterioration $(+) /$ culture $(-)$ (group II) was a group of patients are whose disease state was unstable and active, but at a lower level than the next group. The deterioration $(+) /$ culture $(+)$ (group III) was a group of patients whose disease state was the most active of the three groups. We excluded some patients who had MAC within their sputum but showed no deterioration on chest radiography because such cases were few.

The laboratory results of these three groups are shown in Table 2. Groups II and III showed significantly higher ESR, WBC and CRP values than group I. Regarding serum albumin and body weight, group III showed significantly lower values, than groups I and II. The concentrations of IFN- $\gamma$, IL-10 and TNF$\alpha$ in the culture supernatants of each test tube were significantly higher than in the matched control tube (data not shown). This means that the PBMC of all patients and healthy subjects reacted with the MAC antigen, PPD-B. Therefore we compared the production of cytokines by PBMC in response to stimulation with PPD-B between the patient and the healthy control groups. IFN- $\gamma$ in each of the three patient groups was lower than in the healthy control group. There was no significant difference in the concentration of IFN- $\gamma$ among the three patient groups. The three patient groups showed a tendency to produce higher amounts of IL-10 than the healthy control group; in particular group II and III showed significantly higher levels of IL-10 than the healthy control 
TABLE 3.

Production of IFN- $\gamma$ and IL-10 by peripheral blood mononuclear cells from the patient groups and healthy control group

\begin{tabular}{|c|c|c|c|c|c|}
\hline Group & No & & $\begin{array}{c}\text { Age } \\
\text { (years) }\end{array}$ & $\begin{array}{l}\text { IFN- } \gamma \\
\mathrm{IU} / \mathrm{ml}\end{array}$ & $\begin{array}{l}\mathrm{IL}-10 \\
\mathrm{pg} / \mathrm{ml}\end{array}$ \\
\hline \multirow{2}{*}{$\begin{array}{l}\text { Patients } \\
\text { Group I }\end{array}$} & \multirow[b]{2}{*}{15} & mean & 67.9 & 68.7 & 111.2 \\
\hline & & SD & 12.3 & 75.0 & 78.2 \\
\hline \multirow[b]{2}{*}{ Group II } & \multirow[b]{2}{*}{16} & mean & 69.5 & 75.5 & $184.4^{*}$ \\
\hline & & SD & 11.7 & 87.5 & 181.5 \\
\hline \multirow[b]{2}{*}{ Group III } & \multirow[b]{2}{*}{15} & mean & 66.2 & 61.8 & $159.7 *$ \\
\hline & & $\mathrm{SD}$ & 8.7 & 80.4 & 117.0 \\
\hline \multirow[b]{2}{*}{ Healthy control } & \multirow[b]{2}{*}{15} & mean & 55.2 & 109.6 & 64.3 \\
\hline & & SD & 13.4 & 103.8 & 78.5 \\
\hline
\end{tabular}

${ }^{*}$ । $; \mathrm{p}<0.05$ vs healthy control

TABLE 4.

Production of TNF- $\alpha$ by peripheral blood mononuclear cells from the patient and healthy control groups

\begin{tabular}{lllll}
\hline Group & No & & $\begin{array}{c}\text { Age } \\
\text { (years) }\end{array}$ & $\begin{array}{c}\text { TNF- } \alpha \\
\text { pg/mL }\end{array}$ \\
\hline Patients & & mean & 63.2 & 262.7 \\
Group I & 6 & SD & 13.9 & 139.6 \\
& & & & \\
Group II & 10 & mean & 67.9 & $563.2^{* 1}$ \\
& & SD & 13.8 & 394.1 \\
Group III & & mean & 71.9 & $1,022.7^{* 1}$ \\
& & SD & 4.3 & 622.8 \\
Healthy control & 12 & mean & & $843.3^{* 2}$ \\
& & & & 506.4 \\
& & & & \\
\hline
\end{tabular}

${ }^{*}$; p $<0.05$ vs Group I, ${ }^{* 2}:$ p $<0.01$ vs Group III

TABLE 5.

Production of IFN- $\gamma$ and IL-10 by PBMC from the patients with NB orTB form of group III

\begin{tabular}{lllrrr}
\hline Form & No & & $\begin{array}{c}\text { Age } \\
\text { (years) }\end{array}$ & \multicolumn{1}{c}{$\begin{array}{c}\text { IFN- } \gamma \\
\text { IU/ml }\end{array}$} & $\begin{array}{r}\text { IL-10 } \\
\text { pg/ml }\end{array}$ \\
\hline & & & & & \\
NB & 6 & mean & 66.8 & 71.7 & 167.2 \\
& & SD & 7.4 & 119.0 & 96.4 \\
& & mean & 65.8 & 55.1 & 154.7 \\
TB & 9 & SD & 9.9 & 48.3 & 134.5 \\
\hline
\end{tabular}

TABLE 6.

\begin{tabular}{|c|c|c|c|c|}
\hline Form & No & & $\begin{array}{c}\text { Age } \\
\text { (years) }\end{array}$ & $\begin{array}{r}\text { TNF- } \alpha \\
\mathrm{pg} / \mathrm{ml}\end{array}$ \\
\hline NB & 3 & $\begin{array}{l}\text { mean } \\
\mathrm{SD}\end{array}$ & $\begin{array}{r}72.3 \\
4.0\end{array}$ & $\begin{array}{l}977.5 \\
769.7\end{array}$ \\
\hline TB & 4 & $\begin{array}{l}\text { mean } \\
\text { SD }\end{array}$ & $\begin{array}{r}71.5 \\
5.1\end{array}$ & $\begin{array}{r}1056.6 \\
614.1\end{array}$ \\
\hline
\end{tabular}

group; in particular. Group II and III showed significantly higher levels of IL-10 than the control group (Table 3). TNF- $\alpha$ was significantly lower in group I patients than in the healthy control group. TNF- $\alpha$ of groups II and III was significantly higher than the in group I, and group III showed the highest TNF- $\alpha$ level among them (Table 4).

The patients were classified by clinical form into $35 \mathrm{NB}$ forms and 11 TB forms. Because there were few patients with TB form belonging to group I or II (table 1), the comparison between TB form and NB form was done for group III only. No significant difference in the production of IFN- $\gamma$, IL-10 and TNF$\alpha$ was found between them (Table 5 and 6).

\section{DISCUSSION}

The host defense mechanisms against MAC, a facultative intracellular pathogen, resemble those against Mycobacterium tuberculosis, whereby cellmediated immunity is important [9-11]. After the initial infection, the host macrophages phagocytose MAC and process it. Then they transfer the information of MAC antigen to $\mathrm{T}$ lymphocytes and produce IL-12. IL-12 is thought as an essential cytokine that differentiates naive helper $\mathrm{T}$ cells (Th0) into Th1 cells. Th1 cells produce Th1-type cytokines such as IFN- $\gamma$, IL-2, IL-18, IL-12 and TNF- $\alpha$. These cytokines accelerate the proliferation of Th1 cells and activate macrophages to gain the ability to suppress the proliferation of intracellular parasites and to kill them. While the dominant Th1-type protective immunity against MAC develops, Th1-type cytokines induce delayed type hypersensitivity causing the specific pathological changes of mycobacterial disease such as epithelioid cell granuloma, caseous necrosis and cavity. Once MAC within macrophages is sterilized or inactivated by the specific protective immune mechanisms, the expanded immune working cells 
such as Th1 lymphocytes and activated macrophages finish their role and undergo apoptosis. Consequently the delayed type hypersensitivity diminishes and healing process starts. In these processes the various cytokines produced by lymphocytes and macrophages interact with each other. Many studies on cytokines in protective immunity against MAC have been done with infected mice or cultured cells in vitro. Generally it has been reported [10-17] that Th1-type cytokines such as IFN- $\gamma$ and IL-12 enhance protective immunity, whereas Th2-type cytokines such as IL-6 and IL-10 inhibit it. IL-10 is also known as an anti-inflammatory cytokine. TNF- $\alpha$ is produced by both Th1 and Th2 cells and plays an important role in protective immunity against MAC $[12,13,18,19]$. In addition, it is thought [20] that many other cytokines, chemokines and chemical mediators contribute to protective immune mechanisms. MAC is an environmental resident flora and primary pulmonary MAC disease is frequently found in older persons. Hence the pathogenesis of onset of this disease can be related to a failure of acquired immunity against MAC [21,22].

In this study, we examined the reactivity of PBMC to PPD-B stimulation in patients with primary pulmonary MAC disease at different active stages. We chose IFN- $\gamma$, IL-10 and TNF- $\alpha$ as the representative cytokines working in this disease. The production of IFN- $\gamma$ by the pulmonary MAC patients at any active stage was decreased compared to that of healthy subjects. Depression of cell-mediated immunity in patients with primary pulmonary MAC disease has been recognized by many investigators $[8,23,24]$. On the other hand, the production of IL-10 in the patients was elevated in parallel with the disease activity. Vankayalapati et al. [25] reported that in MAC patients, mycobacterium-stimulated PBMC produced higher concentration of IL-10 but lower concentration of IFN- $\gamma$, IL-12, and TNF- $\alpha$ compared to PBMC from M. avium- sensitive control subjects. They thought that dominancy of the Th2 type reaction over the Th1 type reaction observed in MAC patients would depend on the individual inherent immune reactivity to MAC and might be a critical cause of this disease. Kobayashi et al. [26] and Nagabhushanam et al. [27] also reported that the immune response for MAC was hereditarily defined in a mouse infection model. However, Ueda et al. [28] and Fattorini et al. [29] reported that this difference of immune reactivity was due to antigenicity of infected MAC. They thought that the immune response of the host to the first infection by
MAC to host was critical in the pathogenesis of MAC disease. Further, other investigators consider that cell-mediated immunity falls with development of MAC disease [22,30,31]. In other words, there is an inhibitory feedback system between Th1 cells and Th2 cells to maintain homeostasis of the inner environment of the host, namely Th1/Th2 cell balance theory. Once MAC can escape from acquired protective immune mechanisms and then continue to proliferate, an excessive inflammation results. To inhibit this, Th2 type cells are activated and secrete Th2-type cytokines such as IL-10. As a result, the Th1 type reaction is suppressed. In the group I patients whose disease activity is stable, suppression of the production of TNF- $\alpha$ suggests that the Th2type reaction is dominant over the Th1-type reaction and the suppressed inflammation state continues. However, such suppression should be temporary or reversible because the production of TNF- $\alpha$ will be elevated when the disease entered the active state; indeed the concentration of TNF- $\alpha$ in group III was the highest. This would be a factor responsible for body weight loss and malnutrition state of the patients. IL-10 and transforming growth factor- $\beta$ are not only anti-inflammatory cytokines but also immunosuppressive cytokines which inhibit secretion of IFN- $\gamma$ and TNF- $\alpha[13,15,16,19]$. Thus it is conceivable that the protective immune mechanisms [15,16,31,32] could not adequately function when the $\mathrm{Th} 2$ reaction is dominant over the Th1 reaction. Consequently pulmonary inflammation would gradually progresse and cause destruction of pulmonary tissue.

We think that the difference of clinical character between TB and NB forms of primary pulmonary MAC disease may be a reflection of difference in the inflammation intensity. We compared the production of cytokines in these two forms, but no significant difference was observed.

We conclude that the production of IFN- $\gamma$, IL-10 and TNF- $\alpha$ by PPD-B-stimulated PBMC clearly reflects the immune state of the patients with primary pulmonary MAC disease.

ACKNOWLEDGMENTS: We thanks Dr. Hironobu Tasaka (the former professor, Bacteriology Division in Hiroshima University) and Dr. Eriko Shigeto (National Hiroshima Hospital) for supplying PPD-B.

\section{REFERENCES}

1. Nightingale SD, Byrd LT, Southern PM, Jockusch JD, 
Cal SX et al. Mycobacterium avium-intracellulare complex bacteremia in human immunodeficiency virus positive patients. J Infet Dis 1992; 165:1082-1085.

2. Prince DS, Peterson JM, and Steiner RM. Infection with Mycobacterium avium complex in patients without predisposing conditions. N Engl J Med 1989; 321:863-868.

3. Reich JM, and Johnson RE. Mycobacterium avium complex pulmonary disease-incidence, presentation, and response to therapy in a community setting. Am Rev Resp Dis 1991; 143:1381-1385.

4. Harada S, Harada Y, Ochiai S, Emori M, Kajiki A et al. A clinical study of deceased cases of pulmonary Micobacterium avium complex (MAC) disease: in contrast with survived cases followed-up for 5 years or longer. Kekkaku 2002; 77:709-716. (in Japanese)

5. Harada S, Harada Y, Ochiai S, Emori M, Kajiki A et al. A clinical study on cases with pulmonary Micobacterium avium complex (MAC) diease followed up for more than 10 years. Kekkaku 2003; 78:517-523. (in Japanese)

6. American Thoracic Society: Diagnosis and treatment of diseases caused by nontuberculous mycobacteria. Am J Respir Crit Care Med 1997; 156:s1-s25.

7. Harada Y, Harada S, Kajiki A, Kitahara Y, Takamoto M et al. Immunological studies of pulmonary infection with atypical Mycobacteria. II Depression of in vitro PPDinduced lymphocyte proliferation in patients with pulmonary atypical Mycobacteria. Kekkaku 1990; 65:341348. (in Japanese)

8. Tasaka H. Skin reaction test using PPD-B Kekkaku 1993; 68:47-50. (in Japanese)

9. Hartmann P, and Plum G. Immunological defense mechanisms in tuberculosis and MAC-infection. Diagn Microbiol Infect Dis 1999; 34:147-152.

10. Denis M. Growth of Mycobacterium avium in human monocytes: identification of cytokines which reduce and enhance intracellular microbial growth. Eur J Immunol $1991 ; 21: 391-395$.

11. Danelishvilli L, and Bermudez LE. Role of type I cytokines in host defense against Mycobacterium avium infection. Curr Pharm 2003; 9:61-65.

12. Appelberg R. Protective role of interferon gamma, tumor necrosis factor alpha and interleukin-6 in Mycobacterium tuberculosis and Mycobacterium avium infections. Immunobiology 1994; 191:520-525.

13. Appelberg R, Castro AG, Pedrosa J, Silva RA, Orme IM et al. Role of gamma interferon and tumor necrosis factor alpha during T-cell-independent and -dependent phases of Mycobacterium avium infection. Infect, Immun 1994; 62:3962-3971.

14. Bermudez LE, Wu M, and Young LS. Interleukin-12stimulated natural killer cells can activate human macrophages to inhibit growth of Mycobacterium avium. Infect Immun 1995; 63:4099-4104.

15. Bermudez LE, and Champsi J. Infection with Mycobacterium avium induces production of interleukin10 (IL-10), and administration of anti-IL-10 antibody is associated with enhanced resistance to infection in mice Infect Immun 1993; 61:3093-3097.

16. Denis $M$, and Ghadirian E. IL-10 neutralization augments mouse resistance to systemic Mycobacterium avium infections. J Immunol 1993; 151:5425-5430.

17. Bermudez LE, Wu M, Petrofsky $M$, and Young LS. Interleukin-6 antagonizes tumor necrosis factor-mediated mycobacteriostatic and mycobactericidal activities in macrophages. Infect Immun 1992; 60:4245-4252.

18. Suzuki K, Lee WJ, Hashimoto T, Tanaka E, Murayama $T$ et al. Recombinant granulocyte-macrophage colonystimulating factor (GM-CSF) or tumour necrosis factoralpha (TNF-alpha) activate human alveolar macrophages to inhibit growth of Mycobacterium avium complex. Clin Exp Immunol 1994; 98:169-173.

19. Denis M. Modulation of Mycobacterium avium growth in vivo by cytokines: involvement of tumour necrosis factor in resistance to atypical mycobacteria. Clin Exp Immunol 1991; 83:466-471.

20. Champsi J, Young LS, and Bermudez LE. Production of TNF-alpha, IL-6 and TGF-beta, and expression of receptors for TNF-alpha and IL-6, during murine Mycobacterium avium infection.Immunology 1995; 84:549-554.

21. Bermudez LE, Wagner D, and Sosnowska D. Mechanisms of Mycobacterium avium pathogenesis. Arch Immunol Ther Exp (Warsz) 2000; 48:521-527.

22. Tomioka H. Attempts to elucidate reasons why mycobacterial infections are intractable, by using an experimental mouse infection model. Nihon Hansenbyo Gakkai Zasshi 1996; 65:155-165. (in Japanese)

23. Ochiai S, Harada S, and Harada Y. Immunological studies in the cases of pulmonary Mycobacterium avium complex infection without predisposing conditions. Nihon Kokyuki Gakkai Zasshi 2004; 42:232-238. (in Japanese)

24. Tsuyuguchi I, Shiratsuchi H, Okuda Y, and Yamamoto $\mathrm{Y}$. An analysis of in vitro $\mathrm{T}$ cell responsiveness in nontuberculous mycobacterial infection. Chest 1988; 94:822829.

25. Vankayalapati R, Wizel B, Samten B, Griffith DE, Shams $\mathrm{H}$ et al. Cytokine profiles in immunocompetent persons infected with Mycobacterium avium complex. J Infect Dis 2001; 183:478-484.

26. Kobayashi K, Nakata N, Kai M, Kasama T, Hanyuda $Y$ et al. Decreased expression of cytokines that induce type 1 helper $\mathrm{T}$ cell/interferon-gamma responses in genetically susceptible mice infected with Mycobacterium avium. Clin Immunol Immunopathol 1997; 85:112-116.

27. Nagabhushanam V, and Cheers C. Non-major histocompatibility complex control of antibody isotype and Th1 versus Th2 cytokines during experimental infection of mice with Mycobacterium avium. Infect Immun 2001; 69:1708-1713.

28. Ueda W, Fujiwara H, Tsuyuguchi I, Kuroki T, and Yano I. Increased production of interleukin- 10 by human blood monocytes stimulated with Mycobacterium avium-intracellulare complex. Kansenshogaku Zasshi 1998; 72:753760. (in Japanese)

29. Fattorini L, Xiao Y, Li B, Santoro C, Ippoliti F et al. Induction of IL-1 beta, IL-6, TNF-alpha, GM-CSF and G-CSF in human macrophages by smooth transparent and smooth opaque colonial variants of Mycobacterium avium. J Med Microbiol 1994; 40:129-133. 
30. Azouaou N, Petrofsky M, Young LS, and Bermudez LE. Mycobacterium avium infection in mice is associated with time-related expression of Th1 and Th2 CD4+ Tlymphocyte response. Immunology 1997; 91:414-420.

31. Bermudez LE, and Young LS. Recombinant granulocytemacrophage colony-stimulating factor activates human macrophages to inhibit growth or kill Mycobacterium avium complex. J Leukoc Biol 1990; 48:67-73.

32. Denis M, and Gregg EO. Recombinant tumour necrosis factor-alpha decreases whereas recombinant interleukin6 increases growth of a virulent strain of Mycobacterium avium in human macrophages. Immunology 1990; 71:139-141. 